\title{
Characteristics of wet-snow avalanche activity: 20 years of observations from a high alpine valley (Dischma, Switzerland)
}

\author{
Stefano Baggi · Jürg Schweizer
}

Received: 19 December 2007/ Accepted: 9 November 2008/Published online: 29 November 2008

(C) Springer Science+Business Media B.V. 2008

\begin{abstract}
The occurrence of wet-snow avalanches is, in general, poorly understood. For 20 years (winters of 1975-1976 to 1994-1995), the avalanche activity has been observed in the Dischma valley near Davos (Eastern Swiss Alps). The study area comprises a large starting zone of north-easterly aspect $(2,300 \mathrm{~m}$ a.s.l.) with several avalanche paths. We have analyzed the occurrence data in combination with meteorological and snowpack data collected at an elevation of 2,090 m a.s.l. During the 20-year observation period, almost 800 wet-snow avalanches were observed, about 4.5 times more loose snow avalanches than slab avalanches. Considering both types of avalanches jointly, snow depth, precipitation and air temperature showed the highest correlation with avalanche activity. Most loose snow avalanches occurred when air temperature was high and/or after a precipitation period. Slab avalanches occurrence was primarily related to warm air temperatures and snowpack properties such as the isothermal state and the existence of capillary barriers. Radiation did not show up as a significant variable. The results suggest that in a transitional snow climate wet-snow avalanches are, as dry snow avalanches, often related to precipitation events, and that wet slab instability strongly depends on snowpack properties in relation to warming of the snowpack and melt water production.
\end{abstract}

Keywords Snow avalanche $\cdot$ Wet snow $\cdot$ Snow cover $\cdot$ Avalanche forecasting

\section{Introduction}

Compared to dry snow avalanches that are well studied, wet-snow avalanches get relatively few attention and are, for example, not covered in a recent review on avalanche formation (Schweizer et al. 2003a). However, wet-snow avalanches represent a major problem in mountain ranges with a predominately maritime snow climate. There, wet slab avalanches are often triggered by rain (McClung and Schaerer 2006), and occasionally occur due to glide on e.g. impermeable rock beds (Clarke and McClung 1999). In mountain ranges with

S. Baggi · J. Schweizer $(\bowtie)$

WSL Institute for Snow and Avalanche Research SLF, Flüelastrasse 11, 7260 Davos Dorf, Switzerland e-mail: schweizer@slf.ch 
a transitional snow climate, wet-snow slab avalanches typically occur in spring when the snowpack warms up and melt water starts to percolate (or when it rains on a dry snowpack). These deep wet slabs are difficult to forecast since their release depends on the complex interaction of water, topography and snowpack layering. Wet-snow avalanches imply by definition the existence of water in the snowpack, i.e. the snow temperature in at least some layers of the snowpack, in the starting zone has to be equal to $0^{\circ} \mathrm{C}$.

Although, it is perceived that air temperature is critical for forecasting wet-snow avalanches (McClung and Schaerer 2006), once at least parts of the snowpack have warmed up to $0^{\circ} \mathrm{C}$, it is usually not possible to use air temperature as a reliable predictor of instability (Armstrong 1976; Kattelmann 1985). In general, the so-called contributory factors for wetsnow avalanches are not as well established as they are for dry-snow slab avalanches. Schneebeli (2004) identified four reasons for the poor predictability of wet-snow avalanches. Most of those are related to the assumption that the critical state of instability is achieved under only very special conditions so that timing and small differences in forcing become crucial-in other words the sensitivity to small perturbations (triggers) is highly non-linear.

Schneebeli (2004) has pointed out the importance of water flow in the snowpack and, in particular, the relevance of capillary barriers for the mechanism of wet-snow slab avalanche release. The natural layering of the snow cover (stratification) resulting from a series of individual snowfalls can have an important influence on the movement of water flow through the snowpack. In general, boundaries between two snow layers of different textures can either impede or accelerate downward flow (Male and Gray 1981). In the context of wet-snow avalanche formation, textural discontinuities and impermeable ice lenses are of particular importance. Fine-over-coarse layering can create capillary barriers so that water is stored above and eventually might flow along the textural boundary (Jordan 1996). Hence, a high liquid water content is not restricted to the layers above crusts as often is supposed (e.g. McClung and Schaerer 2006). In a transitional snow climate, the vertical water movement through the snow cover might as much be affected by the existence of capillary barriers due to fine-over-coarse layering as by impermeable ice lenses or crusts.

If the water content above a textural discontinuity increases, wet-snow metamorphism accelerates. However, its effect on the mechanical properties of wet snow is still poorly understood-partly due to the experimental difficulties with testing wet snow. Below a volumetric water content of about 7\%-commonly considered as about the water content at the transition from the pendular to the funicular regime of unsaturated water flow (e.g. Colbeck 1975) - the mechanical strength seems not to decrease significantly (Brun and Rey 1987). Correspondingly, Kattelmann (1987) found increased wet-snow avalanche activity if the volumetric water content exceeded $7 \%$. Preliminary results from some recent field experiments where initially dry snow layers were artificially wetted suggest that the hardness might decrease already at lower water content than 7\% (Techel et al. 2008).

Whereas, it is commonly accepted that snowpack stratigraphy needs to be considered for predicting dry-snow slab avalanche release (Schweizer and Föhn 1996), snow stratigraphy has so far not explicitly been considered in numerical forecasting of wet-snow avalanches (e.g. McClung and Tweedy 1994; Romig et al. 2005; Zischg et al. 2005).

The aim of the present study was to characterize wet-snow avalanche activity and thereby improve our understanding of wet-snow avalanche formation. We were particularly interested into determining how snowpack properties-other than snow temperatureaffect the formation of wet-snow avalanches. For that purpose, we have analyzed 20 years 
of avalanche occurrence data in combination with meteorological and snowpack data from the Dischma valley near Davos (Eastern Swiss Alps).

\section{Methods}

\subsection{Study area and instrumentation}

The Stillberg study area is located in the Dischma valley, south-east of Davos (Switzerland) $\left(46^{\circ} 46^{\prime} \mathrm{N}, 9^{\circ} 51^{\prime} \mathrm{E}\right)$ (Fig. 1). Various studies at this site have been performed since the 1950s with the primary focus on reforestation and, in general, on the interaction between forest, snow cover and avalanches. In the course of these projects, avalanche activity has consistently been observed for many years. The avalanche starting zones are located between 2,000 and 2,300 $\mathrm{m}$ a.s.l. and have north-easterly aspect. The average slope inclination is about $38^{\circ}$.

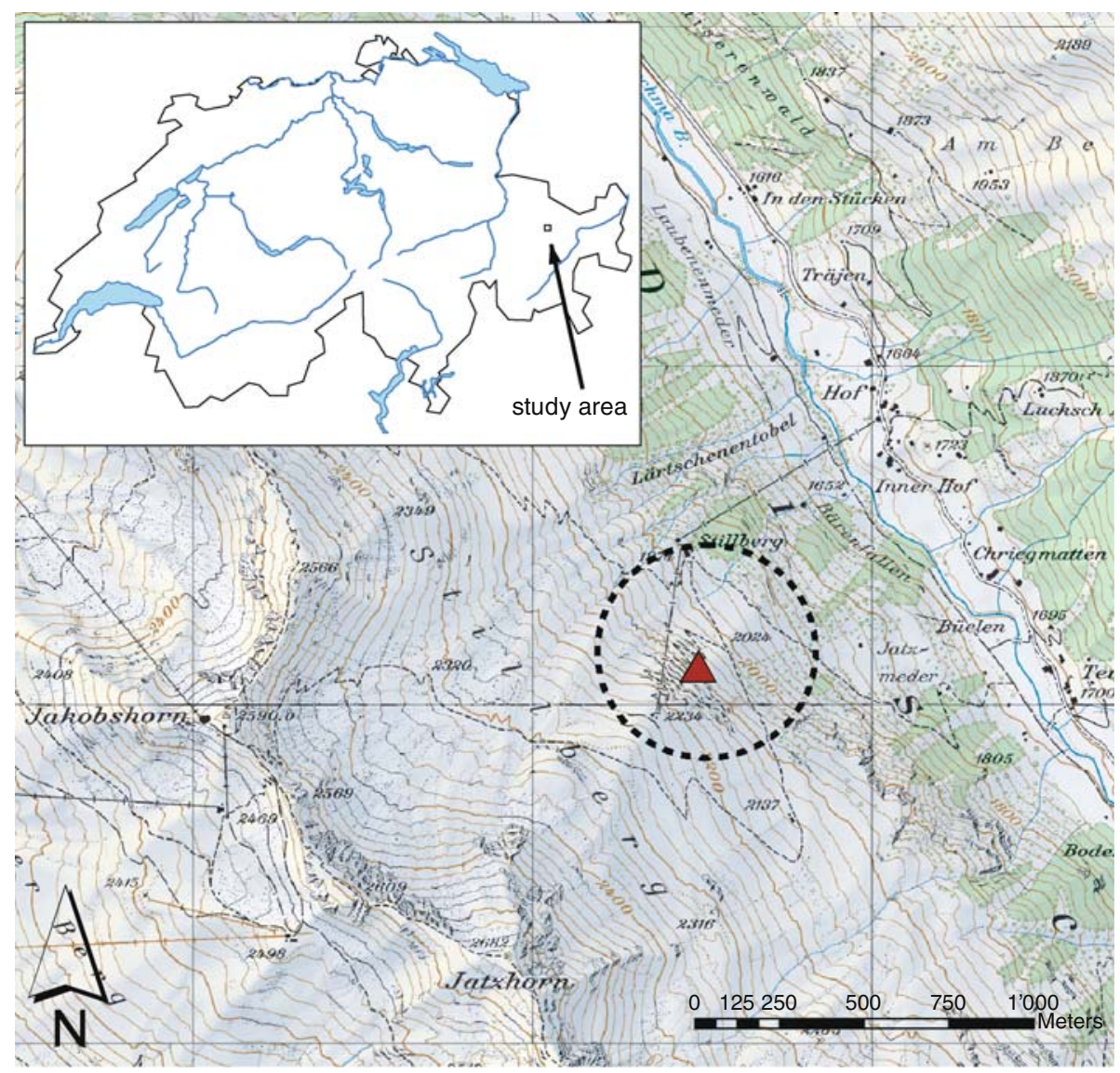

Fig. 1 Map of study area $\left(46^{\circ} 46^{\prime} \mathrm{N}, 9^{\circ} 51^{\prime}\right.$ E) in the eastern Swiss Alps (see inset) Stillberg study site is indicated with dashed circle; triangle shows location of AMS (Map sources: PK25 2006 Swisstopo (JA082256), ${ }^{\circ}$ BFS, GEOSTAT) 
At 2,090 $\mathrm{m}$ a.s.l., an automatic weather station (AWS) is located that since 1975 records-among other elements-air temperature, soil surface temperature, snow temperatures, relative humidity, precipitation, snow depth, global radiation (incoming and reflected short wave radiation measured with two Kipp\&Zonen CM11 pyranometers), wind speed and wind direction. Near the AWS, bimonthly manual snow profiles have been recorded including grain type and size, snow hardness index, snow temperature, estimated liquid water content (wetness), snow density and ram hardness profile (Colbeck et al. 1990).

Avalanche activity was observed on a daily basis. Records include date (and if possible time), location, elevation, aspect, estimated fracture depth, estimated avalanche width and length, and avalanche characteristics according to the international morphological classification of avalanches (de Quervain et al. 1973).

\subsection{Statistical analysis}

Meteorological and snowpack data were related to avalanche occurrence data applying standard univariate and multivariate statistics. The non-parametric Mann-Whitney $U$-test was used to relate single variables to avalanche occurrence. For categorical variables, the data were cross-tabulated and a Yates' corrected Pearson $\chi^{2}$ statistic was calculated (Spiegel and Stephens 1999). For the multivariate analyses primarily, the classification tree method was used (Breiman et al. 1998). The classification tree method was previously applied for avalanche forecasting, for example, by Davis et al. (1999), and by Hendrikx et al. (2005). A level of significance $p=0.05$ was chosen to decide whether the observed correlations or differences were statistically significant.

\section{Data}

For the analysis, we have chosen 20 years of observations from 1975-1976 to 1994-1995 (October-June), since for this period data from the AWS were available, avalanche occurrence observations were considered as consistent (they become less so towards the end of the 1990s) and the period seemed long enough to cover a variety of snow and avalanche conditions.

The avalanche occurrence data only included natural releases and predominantly wetsnow avalanches. First, the wet-snow avalanches were selected including slab and loose snow avalanches. Then, the avalanches were classified according to their size using the Canadian size class system (1-4) (McClung and Schaerer 2006) in order to calculate a daily avalanche activity index (AAI). The index is a weighted sum of observed avalanches per day with weights of $0.01,0.1,1$ and 10 for size classes 1-4, respectively (Schweizer et al. 2003b). Depending on the AAI, days were classified into non-avalanche days $(\mathrm{AAI}=0)$, avalanche days $(\mathrm{AAI}>0)$, significant avalanche days $(\mathrm{AAI} \geq 1)$ and slab avalanche days (AAI $>0$ and at least one wet slab avalanche occurrence).

To have a matching data set of days without wet-snow avalanche occurrence, we randomly selected the same number of non-avalanche days taking into account the frequency of wet-snow avalanche days per month (so that there was an equal number of avalanche and non-avalanche days in any one month).

For the meteorological dataset radiation, precipitation, snow depth, relative humidity and air temperature data from the AWS were selected. Besides mean, and occasionally maximal and minimal values per day of these variables, a number of accumulated and 
derived variables were calculated such as the positive air temperature summed over the 3 or 5 preceding days, resulting in a total of 20 meteorological variables (Table 1).

To characterize the snow cover, the snow temperature $50 \mathrm{~cm}$ above ground from the AWS was used as well as a number of variables derived from the snow profiles that were taken twice a month. Those included were snow water equivalent, average density, average ram penetration resistance, thickness of snow cover, which was classified as moist or wet (absolute in $\mathrm{cm}$, and relative to total snow depth in \%), and number of days since isothermal state has been reached. Based on the ram hardness profile, profiles were classified into those with rather well-consolidated base and those with rather weak, cohesionless basal layers (Schweizer and Wiesinger 2001). Based on snow stratigraphy, the number of potential capillary barriers was assessed. The capillary barriers were classified into three classes according to their potential effectiveness (depending on grain size difference and minimal grain size) (Table 2). In addition, an index - the weighted sum of the number of capillary barriers-was calculated. In total, we considered 36 predictor variables (Table 1).

\section{Results}

\subsection{Avalanche activity}

During the 20-year observation period, a total of 771 wet-snow avalanches on 148 days were observed. The majorities (630) were wet loose snow avalanches, i.e. about 4.5 times more loose snow avalanches than slab avalanches were recorded. From the 148 days, on 94 days only loose snow avalanches, on 24 days only wet-snow slab avalanches, and on the remaining days both avalanche types were observed. There were many large loose snow avalanches with considerable destructive power. Nevertheless, considering avalanche size the proportion of wet loose snow avalanches to wet-snow slab avalanches reduced to 0.68 , i.e. slab avalanches clearly dominated the avalanche activity expressed in terms of the AAI which is a measure of destructive power (Fig. 2).

Not surprisingly, $90 \%$ of the avalanches, of the avalanche days and the avalanche activity occurred during the three months of March, April and May (i.e. during the melting season) (Fig. 3). Whereas, most avalanches occurred in May, the activity peaked in March when most slab avalanches were recorded ( $42 \%$ or 59 avalanches). This is the time of the onset of the melting season. The snow cover $(2,100 \mathrm{~m}$ a.s.l., NE) became on average isothermal at the beginning of April (2nd April). Still, a considerable number of slab avalanches were recorded in April (36) and May (25).

There was considerable year-to-year variation in avalanche activity. There were winters with very few $(<10)$ avalanches and winters with very many $(>90)$ avalanches. There was a trend to more wet slab avalanches in winters with weak basal snowpack layers (primarily due to depth hoar formation in early winter) than with well consolidated basal layers, and vice versa for wet loose snow avalanches. However, the differences were statistically not significant ( $U$-test, $N=20, p=0.62$ and $p=0.32$ for slab and loose snow avalanches, respectively). The only significant difference found $(p=0.045)$ was that the number of loose snow avalanches was higher in above-average snow years than in below-average snow years.

\subsection{Qualitative observations}

We first qualitatively analyzed some of the more intense avalanche winters. In 8 out of the 20 winters, the avalanche activity was high (i.e. number of wet-snow avalanches $\geq 30$ and 
Table 1 Meteorological and snowpack variables (36)

\begin{tabular}{|c|c|c|c|c|}
\hline \multirow[t]{2}{*}{ Variable } & \multicolumn{2}{|l|}{ Median (or \#) } & \multirow{2}{*}{$\begin{array}{l}\text { All days } \\
p\end{array}$} & \multirow{2}{*}{$\begin{array}{l}\text { Slab days } \\
p\end{array}$} \\
\hline & $\mathrm{nAvD}$ & AvD & & \\
\hline Radiation $1 \mathrm{~d}\left(\mathrm{~W} / \mathrm{m}^{2}\right)$ & 3.9 & 4.2 & 0.57 & 0.60 \\
\hline Radiation $3 \mathrm{~d}\left(\mathrm{~W} / \mathrm{m}^{2}\right)$ & 12.1 & 12.7 & 0.34 & 0.37 \\
\hline Radiation $5 \mathrm{~d}\left(\mathrm{~W} / \mathrm{m}^{2}\right)$ & 20.7 & 21.0 & 0.28 & 0.47 \\
\hline Air temperature $1 \mathrm{~d}\left({ }^{\circ} \mathrm{C}\right)$ & 0.0 & 2.2 & 0.008 & 0.11 \\
\hline Air temperature $1 \mathrm{~d}, \min \left({ }^{\circ} \mathrm{C}\right)$ & -2.2 & -0.41 & 0.004 & $\mathbf{0 . 0 3 9}$ \\
\hline Air temperature $1 \mathrm{~d}, \max \left({ }^{\circ} \mathrm{C}\right)$ & 3.2 & 5.3 & 0.008 & 0.28 \\
\hline Air temp. difference $1 \mathrm{~d}\left({ }^{\circ} \mathrm{C}\right)$ & 0.4 & 0.49 & 0.86 & 0.70 \\
\hline Air temp. difference $2 \mathrm{~d}\left({ }^{\circ} \mathrm{C}\right)$ & 0.18 & 1.1 & 0.74 & 0.97 \\
\hline Air temp. difference $3 \mathrm{~d}\left({ }^{\circ} \mathrm{C}\right)$ & 0.89 & 1.2 & 0.49 & 0.54 \\
\hline Soil surface temperature $\left({ }^{\circ} \mathrm{C}\right)$ & 0.05 & 0.04 & 0.91 & 0.66 \\
\hline Precipitation $1 \mathrm{~d}(\mathrm{~mm})$ & 0.15 & 0.2 & 0.39 & 0.53 \\
\hline Precipitation $3 \mathrm{~d}(\mathrm{~mm})$ & 2.9 & 5.8 & 0.005 & 0.59 \\
\hline Snow depth (m) & 0.94 & 1.0 & $<0.001$ & 0.13 \\
\hline Difference in snow depth $3 \mathrm{~d}(\mathrm{~m})$ & -0.02 & -0.05 & 0.12 & 0.005 \\
\hline Wind speed $(\mathrm{m} / \mathrm{s})$ & 1.4 & 1.5 & 0.86 & 0.50 \\
\hline Relative humidity $1 \mathrm{~d}(\%)$ & 69.5 & 70.2 & 0.36 & 0.66 \\
\hline Relative humidity $3 \mathrm{~d}(\%)$ & 208 & 216 & 0.08 & 0.68 \\
\hline Positive air temperature $1 \mathrm{~d}\left({ }^{\circ} \mathrm{C}\right)$ & 0.02 & 2.2 & 0.014 & 0.08 \\
\hline Positive air temperature $3 \mathrm{~d}\left({ }^{\circ} \mathrm{C}\right)$ & 2.3 & 5.9 & 0.011 & 0.005 \\
\hline Positive air temperature $5 \mathrm{~d}\left({ }^{\circ} \mathrm{C}\right)$ & 5.9 & 9.1 & 0.15 & 0.013 \\
\hline Rain (mm) & 0.0 & 0.0 & 0.015 & 0.024 \\
\hline *Rainy day (yes/no) & $20 / 128$ & $37 / 111$ & 0.012 & 0.003 \\
\hline *Rain on day before (yes/no) & $20 / 128$ & $30 / 118$ & 0.12 & 0.14 \\
\hline Snow water equivalent (mm) & 343 & 386 & 0.01 & 0.24 \\
\hline Density $\left(\mathrm{kg} / \mathrm{m}^{3}\right)$ & 298 & 302 & 0.92 & 0.07 \\
\hline Ram resistance $(\mathrm{N})$ & 47.6 & 47 & 0.48 & 0.56 \\
\hline $\begin{array}{l}\text { Snow temperature } 50 \mathrm{~cm} \text { above ground } \\
\qquad(N=198)\left({ }^{\circ} \mathrm{C}\right)\end{array}$ & -0.32 & -0.11 & 0.002 & 0.005 \\
\hline Portion of isothermal snowpack layers (\%) & 53.7 & 56.3 & 0.41 & 0.65 \\
\hline Portion of moist or wet snowpack layers (\%) & 44.8 & 51.0 & 0.91 & 0.89 \\
\hline Day since isothermal state was reached $(N=166)$ & 26 & 19 & 0.008 & $\mathbf{0 . 0 2 9}$ \\
\hline Index of capillary barriers & 0.0 & 0.1 & 0.14 & 0.014 \\
\hline *Presence of weak layer (yes/no) & $140 / 8$ & $138 / 10$ & 0.63 & 0.69 \\
\hline *Consolidation of basal layers (poor/good) & $142 / 6$ & $145 / 3$ & 0.31 & 0.77 \\
\hline *\# Of weak capillary barriers $(0 / 1 / 2 / 3 / 4)$ & $71 / 53 / 21 / 2 / 1$ & $79 / 54 / 15 / 0 / 0$ & 0.35 & 0.27 \\
\hline *\# Of intermediate capillary barriers $(0 / 1 / 2)$ & $103 / 34 / 11$ & $89 / 49 / 10$ & 0.15 & 0.018 \\
\hline *\# Of strong capillary barriers $(0 / 1 / 2)$ & $112 / 34 / 2$ & $106 / 34 / 8$ & 0.15 & 0.13 \\
\hline
\end{tabular}

Median is given for non-avalanche (nAvD) and avalanche days (AvD). Level of significance $p$ is given for contrasting non-avalanche to avalanche days using the $U$-test or-for variables with an asterisk $(*)$-by cross-tabulating the data and calculating the Pearson $\chi^{2}$ statistic (significant variables are given in bold). Contrasting is done for the full dataset ("all days"; $N=296$ ) and for selected cases ("slab days"; $N=107$ ). The latter dataset included only days with a snow depth $>30 \mathrm{~cm}$ and with isothermal layers $(>0 \%)$. In addition, for the avalanche days only days with one or more slab avalanche were considered 
Table 2 Definitions of classes of capillary barriers and their weight for calculating the index describing the existence of capillary barriers

\begin{tabular}{lll}
\hline Potential effectiveness & Criteria & $\begin{array}{l}\text { Weight for } \\
\text { index }\end{array}$ \\
\hline I: Low & Grain size difference $[0.5 \mathrm{~mm} ; 1 \mathrm{~mm}]$, smallest grains $\leq 0.5 \mathrm{~mm}$ & 0.01 \\
& Grain size difference $[1 \mathrm{~mm} ; 1.5 \mathrm{~mm}]$, smallest grains $>0.5 \mathrm{~mm}$ & \\
II: Intermediate & Grain size difference $[1 \mathrm{~mm} ; 1.5 \mathrm{~mm}]$, smallest grains $\leq 0.5 \mathrm{~mm}$ & 0.1 \\
& Grain size difference $[1.5 \mathrm{~mm} ; 2 \mathrm{~mm}]$, smallest grains $>0.5 \mathrm{~mm}$ & \\
III: High & Grain size difference $\geq 1.5 \mathrm{~mm}$, smallest grains $\leq 0.5 \mathrm{~mm}$ & 1 \\
& Grain size difference $\geq 2 \mathrm{~mm}$, smallest grains $>0.5 \mathrm{~mm}$ & \\
\hline
\end{tabular}

Fig. 2 Wet snow avalanche activity per winter (1975-1976 to 1994-1995): a number of loose snow and slab avalanches, b AAI for loose snow and slab avalanches
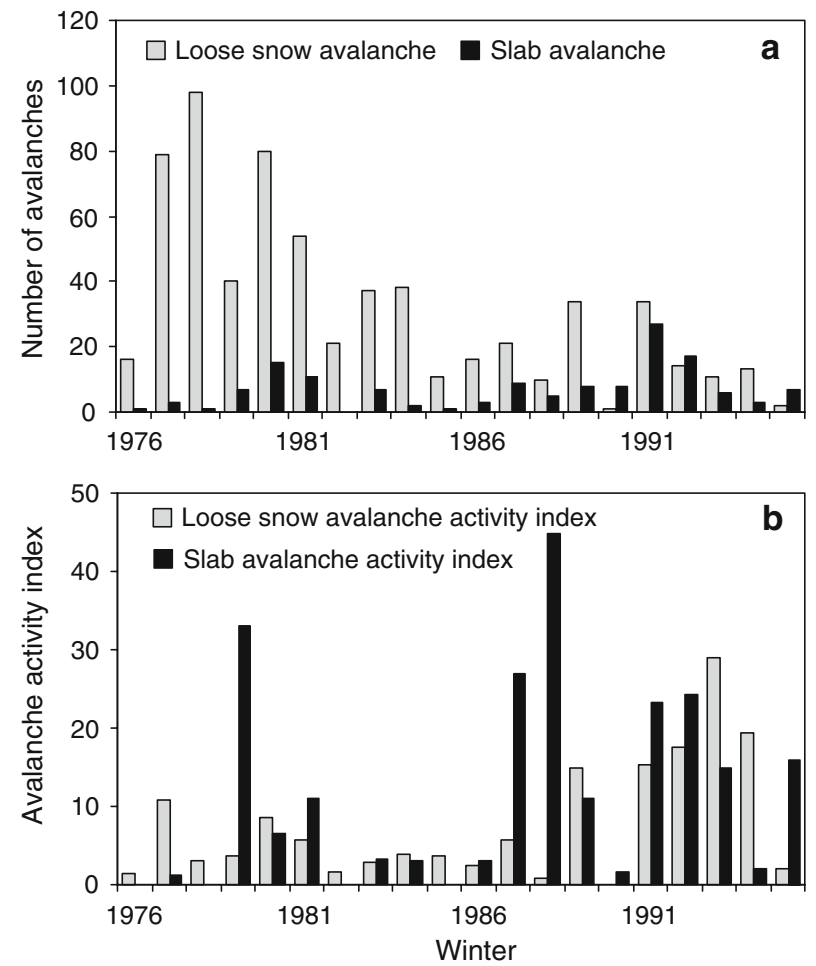

AAI $\geq 10$ ). Figure 4 shows the avalanche occurrence, weather and snow data for the first of the eight winters with high avalanche activity. During this winter (1976-1977), 82 wetsnow avalanches were recorded and $\mathrm{AAI}=12$. The first two wet-snow avalanche events coincided with a significant increase in air temperature. The third event followed a period of warm weather. The day before, there was some precipitation and again a pronounced increase in air temperature. By the middle of April, the snow cover was isothermal. The occurrence in the middle of April was related to precipitation. The remaining avalanche events were at the beginning or after a period of warm weather. Despite warm weather, there were no wet-snow avalanche events in the remaining of the season that was characterized by a strong decrease in snow depth. In other words, as usually, the snowpack remained stable and just melted away. 
Fig. 3 Wet snow avalanche activity per month for the 20 winters from 1975-1976 to 1994-1995: a number of loose snow and slab avalanches, b AAI for loose snow and slab avalanches
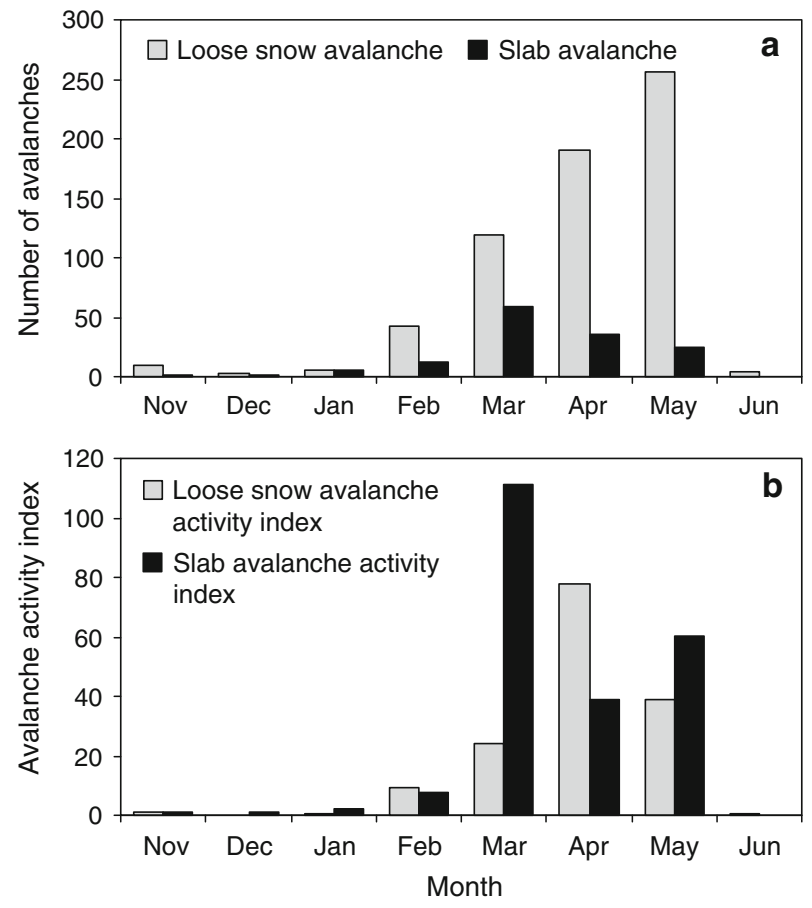

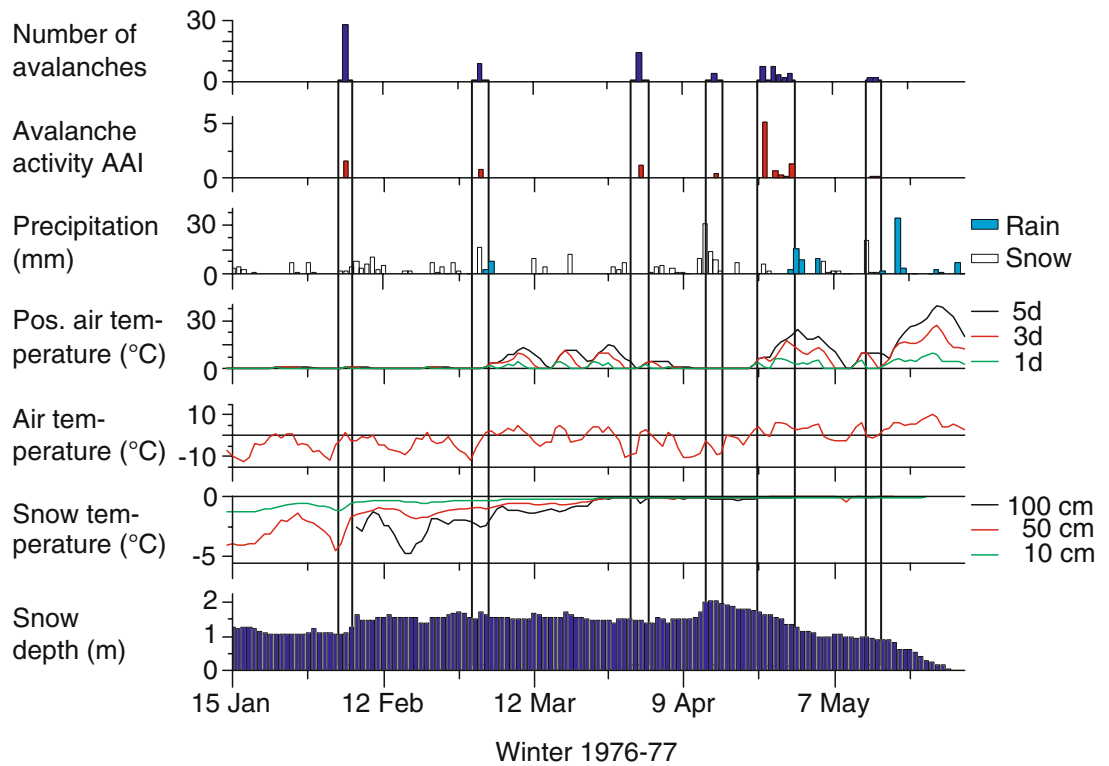

Fig. 4 Avalanche occurrence (number and AAI), weather and snow data during the winter of 1976-1977

Similar observations were made for the other seven winters with high avalanche activity. Although the analysis of these eight winters is merely qualitative and lacks objectivity, some patterns seem to emerge. Increased avalanche activity was typically 
observed (1) during or shortly after a significant increase in air temperature or during periods of warm weather, (2) during or shortly after rain or snowfall and (3) after the entire snowpack had reached an isothermal state. The following statistical analysis will show the relevance of these observations. In particular, whether these observations are useful at all for discrimination, since they might as well appear for negative events, i.e. at non-avalanche days.

\subsection{Statistical analyses}

We first contrasted the meteorological and snowpack variables one by one of all 148 avalanche days to those of the randomly selected 148 non-avalanche days ( $U$-test) (Table 1). Air temperature, snow depth and precipitation, including rain, were the meteorological variables that were best related with wet-snow avalanche occurrence. Except snow water equivalent (which correlated with snow depth), snow temperature at $50 \mathrm{~cm}$ above ground and days since isothermal state was reached, none of the other snowpack variables were significantly related to avalanche occurrence. The radiation variables had no discriminating power as there was hardly any difference in radiation between avalanche and non-avalanche days. The analysis also revealed that there were probably a few misclassifications in regard to wet/dry snow avalanches-despite critical inspection of the occurrence records-since the data suggested that the dataset included some avalanches that were not related to the presence of liquid water in the starting zone.

In a multiple linear regression analysis on AAI, the thickness of isothermal layers (proportion relative to snow depth) and the capillary barriers were identified as significant variables, whereas snow depth was no longer relevant. In the AAI, the wet slab avalanches that are largest and have most destructive power have more weight. As we were particularly interested in the wet slab avalanches, the further analysis is focused on the wet slab avalanche occurrence.

For that purpose, we only considered avalanche days with at least one wet slab avalanche and added two more restrictions: (1) some layers had to be isothermal and (2) the minimal snow depth had to be $30 \mathrm{~cm}$. These conditions reduced the dataset to 34 slab avalanche days and 73 non-avalanche days. The results of the univariate analysis are shown in Table 1. With the focus on slab avalanches, some of the meteorological variables disappeared and two variables related to the presence of capillary barriers became statistically significant.

In summary, wet-snow slab avalanches were significantly $(p<0.05)$ related to the following variables: minimum air temperature, sum of positive air temperatures of 3 or 5 days, change (decrease!) in snow depth over 3 days, rain, snow temperature $50 \mathrm{~cm}$ above ground, days since isothermal state had been reached and existence of capillary barriers. On the other hand, wet loose snow avalanches were significantly related to meteorological variables only: mean, minimum and maximum air temperature, sum of precipitation of 3 days and sum of positive air temperatures of 3 days.

We used the seven above listed variables, which are found to be significantly related to wet-snow slab avalanches, as input variables for a classification tree analysis. The resulting classification tree is shown in Fig. 5. Since not for all days, the two variables snow temperature at $50 \mathrm{~cm}$ above ground, and days since isothermal state was reached were available, the number of cases was reduced to 58. The tree analysis suggests that the first days, after the isothermal state had been reached, were the most critical ones for wet-snow slab avalanches. This might be due to the fact that at this time no melt water channels have developed yet, and hence an enhanced destabilizing water content at a capillary barrier 
Fig. 5 Classification tree to discriminate between days with (SAvD) and without (nAvD) wet snow slab avalanche activity. The three variables appearing at nodes are the days since isothermal state was reached (days_iso), the sum of positive air temperatures of 3 days (Pos_Temp_3d) and the index of capillary barriers (cap_bar_w).

Numbers in brackets indicate the non-avalanche days and the slab avalanche days, respectively

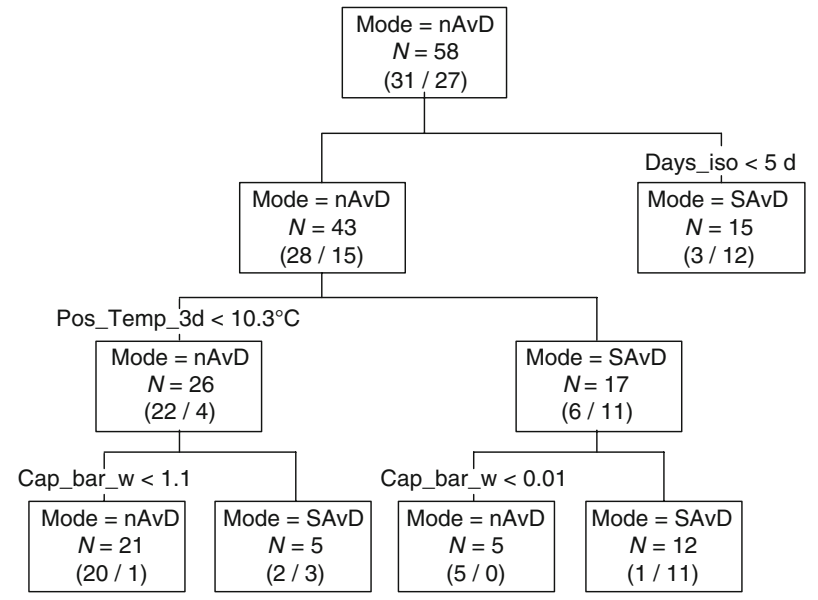

seems more likely. If the snow cover is already isothermal, then the tree suggests that wet slab avalanches are more likely if either it is very warm and still capillary barriers exist, or it is some less warm, but then very strong capillary barriers have to exist. The not crossvalidated classification accuracy was about $88 \%$, whereas the 10 -fold cross-validated accuracy dropped to $71 \%$. The cross-validation showed that the three variables (index of capillary barriers, the days since the isothermal state was reached and the 3-day sum of positive air temperatures) appeared prominently (at least nine times) in the ten classification trees, whereas the other four variables appeared only three times or less. The statistical analyses partly confirmed the qualitative observations.

\section{Conclusions}

We have explored a large dataset of weather, snowpack and avalanche occurrence data in order to get insight into wet-snow avalanche activity. For the first time, we have considered variables describing snowpack characteristics that have been proposed as relevant for wet slab avalanche release such as capillary barriers. Though the results might be partly site specific and influenced by the generally north-east aspect of the starting zones, important conclusions on, for example, the timing of wet-snow slab avalanches should not be site specific since they depend on the state of the snowpack. Though the isothermal state will be reached earlier on south-facing slopes, the mechanism involved in triggering might still be the same. Armstrong (1976) has pointed out the sequence of release as a function of aspect.

In general, a large variability in wet-snow avalanche occurrence over the 20 winters was observed. There was a slight trend of increased wet slab avalanche activity in winters with weak basal layers. This coincides with a common hypothesis that in winters with significant depth hoar formation at the beginning of the season, more wet slab avalanches in spring have to be expected. However, the trend was statistically not significant.

Wet loose snow avalanche activity peaked in May, towards the end of the melting season, whereas wet-snow slab avalanches were mostly observed in March at the beginning of the melting season and subsequently when the snowpack had become isothermal. Avalanche activity in general was often related to precipitation events, in particular rain. 
Loose snow avalanches were most frequently observed with warm air temperatures and/ or rain. Whereas, high air temperatures shortly after the entire snowpack had reached $0^{\circ} \mathrm{C}$ (isothermal snowpack) and the existence of capillary barriers characterized the wet slab avalanche days.

Our analysis suggests that for the release of wet slab avalanches snowpack parameters (including stratification) might be more important than commonly assumed. They might even be as important as in the case of dry-snow slab avalanche formation. Hence, considering snowpack properties might also be the key for the forecasting of wet-snow slab avalanches. However, snowpack monitoring (manual and automatic) as well as simulation is certainly more challenging for wet-snow slab avalanche forecasting since the relevant processes, in particular, water infiltration, are highly non-linear and variable in space and time. The "right" conditions for the release of a wet slab avalanche might prevail for a shorter time (hours) than in the case of dry-snow slab avalanches which may release on weak layers that persist for days, or even weeks.

Supposedly, climate change will affect wet-snow avalanche activity-possibly in respect to timing and location/elevation of occurrence. However, given the considerable lack of understanding of wet-snow avalanche formation it seems premature for any firm statement on possible consequences of climate change on avalanche activity.

Finally, based on the analysis, we suggest three triggering mechanisms for wet-snow avalanches: (1) loss of strength due to water infiltration and storage at capillary barrier, (2) overloading of partially wet (and weakened) snowpack due to precipitation and (3) gradual weakening of (basal) snowpack due to warming of snowpack to $0^{\circ} \mathrm{C}$ and eventual failure of basal layers. Obviously, combinations of these three mechanisms may exist.

Acknowledgements We thank Martin Schneebeli for sharing his expertise on melt-water percolation in seasonal snow covers.

\section{References}

Armstrong RL (1976) Wet snow avalanches. In: Armstrong R, Ives JD (eds) Avalanche release and snow characteristics, San Juan Mountains, Colorado. Sun Juan Avalanche Project, Final report 1971-1975, Occasional paper no. 19. Institute of Arctic and Alpine Research, University of Colorado, Boulder, CO, USA, pp 67-82

Breiman L, Friedman JH, Olshen RA, Stone CJ (1998) Classification and regression trees. CRC Press, Boca Raton, USA, p 368

Brun E, Rey L (1987) Field study on snow mechanical properties with special regard to liquid water content. In: Salm B, Gubler H (eds) Symposium at Davos 1986-avalanche formation, movement and effects, IAHS Publ., 162. International Association of Hydrological Sciences, Wallingford, Oxfordshire, UK, pp 183-193

Colbeck SC (1975) A theory for water flow through a layered snowpack. Water Resour Res 11(2):261-266. doi:10.1029/WR011i002p00261

Colbeck SC, Akitaya E, Armstrong R, Gubler H, Lafeuille J, Lied K, McClung D, Morris E (1990) The international classification of seasonal snow on the ground. International Commission on Snow and Ice (ICSI), International Association of Scientific Hydrology, Wallingford, Oxon, UK, p 23

Clarke JA, McClung DM (1999) Full-depth avalanche occurrences caused by snow gliding, Coquihalla, BC, Canada. J Glaciol 45(151):539-546

Davis RE, Elder K, Howlett D, Bouzaglou E (1999) Relating storm and weather factors to dry slab avalanche activity at Alta, Utah, and Mammoth Mountain, California, using classification and regression trees. Cold Reg Sci Technol 30(1-3):79-89. doi:10.1016/S0165-232X(99)00032-4

de Quervain MR, de Crecy L, LaChapelle ER, Losev K, Shoda M (1973) Avalanche classification. Hydrol Sci Bull 18(4):391-402

Hendrikx J, Owens I, Carran W, Carran A (2005) Avalanche activity in an extreme maritime climate: the application of classification trees for forecasting. Cold Reg Sci Technol 43(1-2):104-116. doi: 10.1016/j.coldregions.2005.05.006 
Jordan R (1996) Effects of capillary discontinuities on water flow and water retention in layered snow covers. In: Agrawal KC (ed) Proceedings of the international symposium on snow and related manifestations, 26-28 September 1994, Manali, India. Snow and Avalanche Study Establishment, Manali, India, pp 157-170

Kattelmann R (1985) Wet slab instability. In: Proceedings of the International Snow Science Workshop, Aspen, Colorado, USA, 24-27 October 1984. ISSW 1984 Workshop Committee, Aspen, CO, USA, pp 102-108

Kattelmann R (1987) Some measurements of water movement and storage in snow. In: Salm B, Gubler H (eds) Symposium at Davos 1986 — avalanche formation, movement and effects, IAHS Publ., 162. International Association of Hydrological Sciences, Wallingford, Oxfordshire, UK, pp 245-254

Male DM, Gray DM (1981) Snowcover ablation and runoff. In: Gray DM, Male DM (eds) Handbook of snow. Principles, processes, management and use. The Blackburn Press, Caldwell, NJ, USA, pp 360-436

McClung DM, Schaerer P (2006) The avalanche handbook. The Mountaineers Books, Seattle, WA, USA, p 342

McClung DM, Tweedy J (1994) Numerical avalanche prediction, Kootenay Pass, British Columbia, Canada. J Glaciol 40(135):350-358

Romig JM, Custer SG, Birkeland KW, Locke WW (2005) March wet avalanche prediction at Bridger Bowl Ski Area, Montana. In: Elder K (ed) Proceedings ISSW 2004. International Snow Science Workshop, Jackson Hole, WY, USA, 19-24 September 2004, pp 598-607

Schneebeli M (2004) Mechanisms in wet snow avalanche release. In: Proceedings ISSMA-2004, international symposium on snow monitoring and avalanches. Snow and Avalanche Study Establishment, India, Manali, India, 12-16 April 2004, pp 75-77

Schweizer J, Föhn PMB (1996) Avalanche forecasting - an expert system approach. J Glaciol 42(141): 318-332

Schweizer J, Wiesinger T (2001) Snow profile interpretation for stability evaluation. Cold Reg Sci Technol 33(2-3):179-188. doi:10.1016/S0165-232X(01)00036-2

Schweizer J, Jamieson JB, Schneebeli M (2003a) Snow avalanche formation. Rev Geophys 41(4):1016. doi: 1010.1029/2002RG000123

Schweizer J, Kronholm K, Wiesinger T (2003b) Verification of regional snowpack stability and avalanche danger. Cold Reg Sci Technol 37(3):277-288. doi:10.1016/S0165-232X(03)00070-3

Spiegel MR, Stephens LJ (1999) Schaum's outline of theory and problems of statistics. McGraw-Hill, New York, p 538

Techel F, Pielmeier C, Schneebeli M (2008). The first wetting of snow: micro-structural hardness measurements using a snow micro penetrometer. In: Proceedings ISSW 2008, International Snow Science Workshop, Whistler BC, Canada, 21-27 September 2008, pp 1019-1026

Zischg A, Fuchs S, Keiler M, Meissl G (2005) Modelling the system behaviour of wet snow avalanches using an expert system approach for risk management on high alpine traffic roads. Nat Hazards Earth Syst Sci 5(6):821-832 